2018

\title{
Multiculturalism to Diversity: Implications from an SLP's Journey
}

Nola T. Radford

University of Tennessee Health Science Center, ntradf@gmail.com

DOI: doi.org/10.30707/TLCSD2.3Radford

Follow this and additional works at: https://ir.library.illinoisstate.edu/tlcsd

Part of the Secondary Education Commons

\section{Recommended Citation}

Radford, Nola T. (2018) "Multiculturalism to Diversity: Implications from an SLP's Journey," Teaching and Learning in Communication Sciences \& Disorders: Vol. 2: Iss. 3, Article 6.

DOI: doi.org/10.30707/TLCSD2.3Radford

Available at: https://ir.library.illinoisstate.edu/tlcsd/vol2/iss3/6

This Reflection on SoTL is brought to you for free and open access by ISU ReD: Research and eData. It has been accepted for inclusion in Teaching and Learning in Communication Sciences \& Disorders by an authorized editor of ISU ReD: Research and eData. For more information, please contact ISUReD@ilstu.edu. 


\title{
Multiculturalism to Diversity: Implications from an SLP's Journey
}

\author{
Abstract \\ The current essay will review significant events in the history of the multicultural movement in the United \\ States over the past 37 years. It is intended to encourage young scholars to study this movement, both \\ the strengths and weaknesses of it, and examine their perceptions of current circumstances and \\ proposed solutions for the discipline of speech-language pathology.
}

\section{Keywords}

multiculturalism, diversity, civil rights 
The purpose of the current essay is to review significant events in the history of the multicultural movement in the United States over the past 37 years, with emphasis on a few examples of its specific impact on the practice of speech-language pathology. This essay is intended to encourage young scholars to study this movement, both the strengths and weaknesses of it, and examine their perceptions of current circumstances and proposed solutions for the discipline of speech-language pathology. In preparing future scholars, it is essential to appreciate the broader context in which current actions and themes have emerged.

George Santayana (1924), a 1950s-era philosopher, essayist, and poet, stated that "those who cannot remember the past are condemned to repeat it" (p. 284); See also Flamm (2018) ${ }^{1}$. Given this statement, if we fail to consider the historical context in which educational practices have evolved and fail to examine critical events that have influenced educational pedagogy, definitions of quality education, and educational access, then we miss critical information for developing a unifying educational pedagogy for the field of speech-language pathology. The journal, Teaching and Learning in Communication Sciences and Disorders (TLCSD), has great potential. An expansion of future aims is recommended to scrutinize scholarship on teaching and learning through the lens of the prevailing historical context.

It is essential to understand the historical context leading to the civil rights movement in the United States and to multiculturalism as a solution to the equitable treatment of students. A basic assumption of this essay is that the historical context advocated for here represents the lens through which we view and interpret experiences. The time period in which we exist influences interpretation of our experiences as well as subsequent action-something which might be labeled "bias". In this regard, our actions always have potential for intended and unintended consequences as a result of numerous factors, including personal preference, interpretation, and value or bias. A formal definition of bias is "an inclination of temperament or outlook; especially : a personal and sometimes unreasoned judgment : prejudice" (Bias, n.d.).

A suggestion is to consider that bias is defined as a personal inclination that is sometimes based on unreasoned judgment. So, it seems that we want to avoid the bias that is based on unreasoned judgment. One strategy to address bias is to recognize the context that has influenced our thinking and pose questions for examining the influences upon current thinking. Given this background, critical and basic questions for scientific inquiry in the field might include:

1. What did happen or is happening in the prevailing culture and why?

2. How are/did the events/happenings influence thinking, teaching and access in speechlanguage pathology?

3. What potential outcomes might we predict based on the historical context?

4. What are the advantages and disadvantages to the profession and/or individuals (whether students or scholars)?

\footnotetext{
${ }^{1}$ The online article by Flamm (2018) provided a thoughtful biographical piece regarding the philosopher and his views on the material world as well as his changing views with age as regarded academe and humanism. On a side note, "theory of mind" is a popular notion currently influencing the articles appearing in the discipline of speechlanguage pathology - a concept that is not as "novel" as we would assume, and one that could be considered in light of the classical notions of reality that Santayana advanced.
} 
5. How are my own experiences influencing my interpretation of events?

6. How is bias affecting professional interpretations, standards and codes of conduct?

In addition to questions that tease out influences on perception and considerations of influences that affect actions toward individuals and populations of people, I suggest also adopting methods to examine the dynamics among groups and individuals. Thus, I urge that we revisit systems theory and the relationship of the macro-level systems (society-at-large, regions, and communities) to the micro-level systems (families and individuals) (See Bronfenbrenner's Ecological Systems Theory (Bronfenbrenner \& Morris, 2007) for more information). If a systems approach to inquiry is adopted, then the necessity is to study problems from the societal level (macro-level) down to the individual level (micro-level), with consideration of the complex interplay across boundaries and multi-directional effects. The current essay is a micro-level examination of my personal journey to teaching and scholarship within a significant period of civil rights action and change, with some attention to the macro-level influences to my advantage and disadvantage. A synopsis of the civil rights movement follows, with narrative largely influenced by the works of Cobbs and Blum (2015). In order to appreciate multiculturalism, I believe one must study and understand the civil rights movement and the broad ramifications for society-at-large and health-related professions in the United States, with a focus on speech-language pathology.

\section{The Civil Rights Movement}

The modern civil rights movement in the United States was a grass-roots movement of men and women, led by a coalition of 60 black ministers, most notably Martin Luther King, Jr. who rose to the forefront as the founder of the Southern Christian Leadership Conference in 1957. The movement was identified with ending the legalized segregation practices of the South, which included separate housing, discrimination in public facilities, denial of the right to vote and unequal access to educational resources. The first blow to legal restriction of access was the earlier ruling by the Supreme Court in the Brown vs. Board of Education case that ruled that segregating children by race was harmful to children. However, as is common with court rulings, the actual implementation of this ruling played out in curious ways across local cities, states and regions. For example, my husband recounts that when schools were integrated in his small hometown, the historically black high school was disbanded and the new uniforms in which the students had taken much pride were destroyed. In other words, prior to forced integration within this local community, there were attempts to fashion segregated practices that were tolerable. The city leaders, in this particular case, attempted to establish separate but equal facilities and experiences. Thus, the Black students had new school uniforms - not used uniforms discarded by the White school. Though segregation was practiced in his particular city, there was concerted effort by local leaders to provide comparable materials and facilities to Black and White students. Thus, the Black students had decent facilities, good teachers and new band uniforms. Moreover, I would suggest that segregation fostered widespread group solidarity (or at least the perception of such) among Blacks in the United States. In addition, the earlier part of the $20^{\text {th }}$ century was more representative of a national Black, collective and more hopeful identity than that which characterizes later periods. My husband is one example from this period. At least in this singular example, the experience of segregation was probably far less traumatizing as practiced day-to-day as those test cases that rose to the highest court levels for litigation. This observation does not mean that 
segregation was fair or without emotional consequences. Consider a reflection by one reared in the South:

When I started school in 1948, my first year was spent in a two-room building, Pine Grove Grammar School, in Bay Minette, that held twenty students. Segregated for the many years that it existed, that building housed six grades taught by two teachers - three grades each. That building is etched in my memory. Little if any care ever went into its maintenance. A paintbrush probably had never touched the structure (Cox, 2004, p. XVII).

Following "advances" in educational practices as a part of desegregation, legislation was passed to address racial divides in other community services. The Civil Rights Act of 1965 guaranteed the rights of all adults to vote, and the subsequent Civil Rights Act of 1968 prohibited discrimination in housing (Cobbs \& Blum, 2015). Debate persists today as to whether legal redress, poverty programs, and other initiatives of the 1960 s to engineer the "Great Society" proposed by President Lyndon Johnson were the appropriate action, and whether such actions corrected long-standing problems or simply complicated race relations. Segregation existed in the North as well as in the South in the 1960s, though a subtler form of segregation was practiced in the North, reinforced often by strict housing policies. Legal remedies addressed direct actions; yet, did not address the prejudices and avoidance of following laws felt unfair and forced. Additionally, the contribution of a longstanding history of ministers and other religious leaders to a national examination of morals related to the treatment of minorities is often left out of professional discussions. Thus, we lose an important perspective in understanding the context in which civil rights leaders' view point, motivation and action were developed. All the complexities of the period cannot be captured in a single essay. What follows is a brief history of multiculturalism, as motivated by the civil rights movement and the impact on speech-language pathology based on my personal development, framed in the context of the country over the past 30 or more years, with emphasis on the ramifications for speech-language pathology.

\section{Multiculturalism}

In time, with the push for civil rights, multiculturalism emerged as an approach to education, public policy, and other areas of social life that encourages a positive view of a multiracial, multiethnic society (Chow, 2014; Battle, 2012). Policies and position papers from American SpeechLanguage-Hearing Association (ASHA) reflect the notion that multiculturalism is an ideal standard worth pursuing so that the profession reflects the general population of the United Sates and respects, as well as responds appropriately to the differences among populations. (i.e., ASHA, 1998, 2010).

The notion of multiculturalism is certainly characteristic of the American ethos ${ }^{2}$ (Boersema, 2018) developed, according to some authors, during the civil rights movement, with regard for the rights of individuals (i.e., Cox, 2004). The major thrust of the civil rights movement initially was to end

\footnotetext{
${ }^{2}$ Throughout American history, there has been debate regarding the relation of individuals to community and the nature of the community (religious vs. secular). See Boersema (2018), with full citation in the references for retrieval. At the time of download, Boersema provided an overview of philosophy in the United States from the beginning of the country to present day, as found in the Internet Encyclopedia of Philosophy: A Peer-Reviewed Academic Resource.
} 
discriminatory practices that limited access and opportunity for housing, education, employment and free association for Blacks in the United States whose ancestry often included slavery or indentured servitude. Slavery, as practiced at one time in the United States, was definitely at odds with the American values of liberty and respect for the individual. However, a basic assumption from disciplines, such as sociology and psychology that address human motivation, was that people often act contradictory to values when there was a perceived threat to survival. So, apparently "good" and personable people routinely engaged in distasteful practices. If one considers that slavery is an ancient tool of subjugation and that it has been universally practiced, then the perspective may elevate the discussion from a deeply personal and emotional response (though valid and understandable), which can bias judgment of events and people. One must understand that slavery, including the residual after effects (i.e. segregation and discrimination) in the United States is only one example of competition for wealth and power, and affected access to everything - education and healthcare, including access to the relatively new profession of speechlanguage pathology. So, earlier in the history of speech-language pathology, there were significant barriers to minorities entering the profession or being served adequately as a client.

This movement, of course, has influenced actions within our own profession, with one result being the establishment of the National Black Association of Speech-Language and Hearing (NBASLH) to address injustices in the larger profession. Founded in 1978, NBASLH represented the culmination of 10 years of work to advance from the Black Caucus to NBASLH. The goal of NBASLH was to address discrepancies in the leadership of the ASHA, professional preparation of clinicians, and appropriate services for minorities with speech-language disorders (Wiggins, 2014).

Competition and conquest are ancient realities in human struggle. The civil rights movement began as a movement to right abuses experienced by Blacks in America as a result of competition and conquest. Multiculturalism was both a response to and an outcome of the civil rights movement (i.e., Bowen, 2016; Bowen \& Correa-Torres, 2017; Chow, 2014).

\section{The Effects of Civil Rights, Multiculturalism and Advances in the 1980s}

The 1980s was a decade of particular significance for me, as I had recently graduated with my Master's degree in speech-language pathology and was about to begin my clinical fellowship in a county school district near where I had grown up. There were essential macro-level system events that influenced my context, including the civil rights movement and general societal approval as well as support of faith-based initiatives. I could not fully appreciate the greater access I was afforded because of the civil rights movement. Micro-level systems included my family and surrounding community. There was a community value for and attention to sharing resources.

My mother and father were very proud that their daughter would serve as a speech-language pathologist in a rural community where her grandmother - my maternal grandmother - had lived and worked as a sharecropper on the vestiges of what once was a large plantation. Similar to many families throughout the United States, my family was a microcosm of diversity, with relatives ranging in age, health, personality, work ethic, hobbies, geographic location, education and so forth. Because of the diversity within my own family, the impact of civil rights was variable- 
having greater consequence for some than others. Our part of the family lived in Arkansas with my paternal grandfather. In contrast to my working-class maternal grandmother, I had a middleclass paternal grandfather who owned land and rental properties and whose stepson (my uncle) was already a prominent chemist. According to family stories, my godmother, with her advanced education at the time ( $8^{\text {th }}$ grade), was among the first to receive her teaching license in Arkansas following emancipation in the late 1800s. In spite of the rich history surrounding me, my knowledge and appreciation of Black people's roles in American history (other than the legacy of slavery) was spotty. My informal cultural education was interrupted by uncertainty about high school and the effects of integration when Jones High School, the feeder high school for minority children, and a school named in honor of a black attorney, Scipio A. Jones, was closed in the early 1970s. Until that point, my circumstance was exceptional in elementary school as my mother's cousin was my second-grade teacher and my mother was a kindergarten teacher at my grade school. My private grade school consisted of all black students who lived within walking distance of the school. Instruction was delivered primarily by Catholic nuns, Sisters of Christian Charity. The principal mission of the order, as presented on their current website, was to "...give witness to Christ through our consecrated life lived in community..." with a mission to "go out to all the world and bring the good news-love, justice, peace." (Sisters of Christian Charity, n.d.) Thus, the subjugation of Blacks in the United States in the South was a perfect dilemma for the Sisters to address. There was concerted effort to educate Black children, regardless of race and income level, and minister to their spiritual needs.

With pressure from the courts to integrate schools, the adults in my community and family, wisely understood the backlash that might occur in pursuit of prevailing authorities seeking new ways to maintain advantage. The Black students who were transferred from Scipio A. Jones High School to the white school were placed in all basic classes in spite of their previous class designations. My teachers from the local Catholic elementary school convinced my parents to send me to a Catholic high school, which was predominantly white. So, with little coaching, my parents took my teachers' advice and sent me to the private, Catholic high school. Of course, the struggles my counterparts experienced in public schools were far greater than what I had experienced. My basic competence as a student was not so directly assaulted. I was in advanced classes. However, when I had difficulties or showed weaknesses in areas, I was less likely to request tutoring and was less likely to be offered any with the paradox of being in advanced classes. For example, my white, lay English teacher told me I produced good poetry, although she also told me I was not good at term papers. It did not occur to me to ask, and she did not offer, to provide some tutoring or extra assignments to improve my mastery of term papers as I made the transition from my neighborhood school to high school. I wonder now if her remarks were indicative of a personal bias that some students are good at term papers and others are not; therefore, there was no need to attempt to teach me with the objective of improving my competence. I can certainly speculate that she had a biased view of my ability to master term papers. One-on-one disagreements between children, with some input from adults to resolve them, are very different from calculated systemic-level manipulation to maintain unfair advantage. This was the lesson that was expressing itself with varying degrees of success in the 1980s. In spite of setbacks, I experienced direct benefit from the grassroots advocacy of my local teachers at the private school who, without reservation, sought to ensure the forward progress of the students in their charge. 
Though I received a good high school education, I graduated at a time when history classes at my private school did not reflect the stories of all people. In spite of making some friends, when the school day ended, I used public transportation to return back to my community, far removed from my new classmates. In many respects we students were curiosities to one another. As in any school, I was faced with some students who were bullies, which is probably a reflection of the competition within the larger society. At every level, without alternative influences or models, we strove for advantage and thus power. These bullies would occasionally joke about race openly in my presence, and discuss, when they thought I could not hear, whether I was competent to serve as Senior Class Secretary even though I was in college preparatory classes along with them. In contrast to these experiences, I made a few very close and fast friends, who were my champions and in whose company I delighted. One of my close friends was my dear friend Patti who reminisced with me recently about growing up in the 1970s and our high school experiences. Because teaching for the nuns was an expression of their faith, they took the charge seriously to educate me as they did the other students. Generally, I was treated well by the nuns-although all the students often complained about the nuns who were very strict. Though the nuns differed in age, academic responsibilities, temperament, and personality, there was the unifying common experience regarding basic notions of the worth of people, the responsibility to teach all well, and the assumption that all students could learn. Were some of the nuns better teachers and more personable than others? The answer is, "yes." However, there were checks and balances as the administrators were typically older and more experienced teachers. Moreover, in the private school, parents were typically regularly involved in the school.

In high school, I did not experience the benefits of schooling in my neighborhood. I no longer had the close proximity of my family or familiar teachers, nor the influence that could be wielded by relatives who were also part of the teaching staff. Yet, I retained advantages from my micro-level supports, such as:

1. Family values centered on the importance of education

2. Good academic preparation

3. Empathetic instructors who were concerned about my learning.

These supports served as conduits for my forward progress and reduced the impact of negative influences. I gravitated to those teachers who showed empathy for me. The benefit of the teachers who responded effectively and interpreted my emotional states appropriately was that they modeled for me ways of empathizing with others. These relationships also buffered me from the depression and lack of resilience that could have resulted from the repeated and subtle insults and rejections, especially regarding race, that occur in high school. In a different venue, I would refer to my teacher's actions in terms of the love they expressed in equipping me properly.

Research and personal experience demonstrate that empathic response is associated with powerful results. Thus, future scholars should continue to examine best practices in terms of empathy and compassion for students and the benefits for student retention, academic performance, graduation, as well as students' cultural competence (a term, by the way, about which I have personal misgivings as it may represent too narrow a parsing of desirable personal competencies). The compassion process model as explained by Lown (2016) is worth further study in terms of the notions complementary to those that characterize multiculturalism and cultural competence to 
promote greater inclusion and access in the field of speech-language pathology. Lown (2016) examines the impact of compassion to the healing process, but with rationales that apply directly to effective teaching, with a caution to be aware of the consequences of the hidden curriculum, "namely uncaring attitudes and behaviors demonstrated by those affected by such environments reinforces uncompassionate cultural norms" (p. 333).

\section{Stumbling into Speech-Language Pathology}

I had no clue as to a potential major with college plans on the horizon. My journey was different from those nurtured in historically Black colleges and universities or those with speech-language pathology professional examples within their mentor circles. However, my particular historical context provided multiple layers of benefit that would lead me to eventually choose speechlanguage pathology as a major and would ensure my completion of the degree. There was a great deal of research centered on a broad range of topics regarding Black children, including intelligence, language use, Black children's academic preparation and many others. These various topics both informed my professional development and lead to a reappraisal of my own personal development as a child.

After taking general classes to meet pattern requirements as an undergraduate at a public university, I reviewed my undergraduate catalog and decided to consider speech-language pathology. I laugh now, as I was mildly frustrated by seeing that one requirement was taking a class called "Articulation Disorders." At that time, I wondered: "How many ways could a child possibly mess up saying r-words?" In general, I was pleased with finding my major and particularly enjoyed the coursework regarding language.

In spite of the targeted efforts that ASHA was instituting at the time, along with efforts of other organizations to promote higher education (i.e., Telluride Association a nonprofit organization established in 1911 and devoted to "transformative educational experiences" in which I participated in 1972 as a high school student), I stumbled into the major. The phenomenon of students finding the major (discipline) indirectly - rather than knowing what it is at the outset of college and choosing a career based on that will most likely continue. I am an example. Speechlanguage pathology is different than something like teaching or medicine, where students are very familiar with the disciplines when they enter college. There will be those students who choose speech-language pathology not because of a role model, a concerted recruitment campaign or scholarship monies, but because of a strategically placed location of facilities on a lone college campus and professors who are actively seeking students who have no clue regarding a major, while possessing the characteristics conducive to good speech-language clinicians. I happened on the description of the major in my college catalog; however, the professors on the college campus bolstered my confidence in the choice I made. Additionally, because of multiculturalism, speechlanguage pathology was changing and the pedagogy was broadening to address differences in language and learning.

\section{Early Mentors and the Influence of Multiculturalism on Notions of Language}

Dr. Orlando Taylor (1986) was an African American scholar whose early career in speechlanguage pathology challenged the notions of dialectal variation as a reflection of inadequate 
language, and was key to an acknowledgement of respect, appropriate assessment, and treatment of minorities. Although I never met Dr. Taylor, as a young clinician and doctoral student, I certainly benefited from reading his work and that of many others (i.e., Noma Anderson (1991), Lorraine Cole (1985), Eugene Wiggins (2014), Walt Wolfram (1999), and others). One professional that I did meet was Dr. Sol Adler, a professor at the University of Tennessee in Knoxville, when I was grappling with a decision regarding whether to pursue a doctorate. Dr. Adler (1988) wrote eloquently about social dialects, stating in the opening of an essay on social dialects,

There is disequilibrium in our professional balance. We properly give enormous weight to our clinical-treatment function with linguistically impaired clients, but give an almost insignificant amount of recognition to our nonclinical teaching and consultative function with linguistically different children and adults (p. 28).

Dr. Adler's assessment of the profession in the 1980s continues to hold validity and raises a number of questions even today. Specifically, with the significant impact of insurance reimbursement upon the profession, are we abandoning attention to "social dialects" and/or dialectal variation as it is an elective "service" with no billable codes? At the same time, while respecting a client's home language, are we sending the message that "standard" English is "White" and certain individuals just have a natural propensity to write and speak it well? This subtle message may be a factor that dissuades some children from studying language and the broader realm of communication. Dialectal variation as one example of communication difference is not the result of race, but the result of many factors, including first language influences, historical "accidents" (i.e., war), geographic location and the degree to which language communities are isolated. Has the lesson of the Ann Arbor ruling in the 1970s been lost? Black parents sued the Ann Arbor School District, with the judge's ruling addressing teachers' responsibility to teach the black children to read, irrespective of their dialect, but with respect for such (Martin Luther King Junior Elementary School Children et al., v. Ann Arbor School District 73 F.Supp. 1371 E.D. Mich. 1979). The ruling extended to "Black English" the same protections as bilingualism as was the law of the land according to the Equal Educational Opportunities Act (20 U.S.C. $§ 1703[f]$ ). The courts did not dictate how to teach, but that children should be taught. This is one example of how multiculturalism influenced change in action about communication and how attitudes about difference had negatively affected access to quality education for Black children in public schools.

Consider now, the changing definitions of multiculturalism as summarized in Figure 1 which indicates key time points in the transition from multiculturalism to diversity. From the time of slavery to Jim Crow in the United States to the civil rights period, blacks were seeking to eliminate unfair advantage and discriminatory practices that limited opportunity and access. During the 1960s, multiculturalism was a rebuttal to the deprivation model, a suggestion that Black children did not perform well due to limited and/or poor experiences (i.e., poverty) (Burgess, Burl, \& Calhoun, 1989). Emphasis on black pride and cultural affirmation increased in popular media and educational practices. The 1970s were characterized by forced integration in the remaining districts throughout the country that resisted court orders. Toward the 1980s, the definition of multiculturalism was modified by many scholars to address diverse populations and the advantages of multiethnic society. Currently, the definition is undergoing modification yet again to emphasize diversity, with racial-ethnic minorities, women, and others grouped under this umbrella term of 
diversity. Both terms (multiculturalism and diversity) reflect a valuing of inclusion. When considering those who are more vulnerable to exclusion, consider the interplay of race-ethnicity, gender, class and language background. According to Testa and Egan (2014), diversity in higher education includes diversity in the student body including diversity of economic background. Poverty is associated with greater risk for success in higher education.

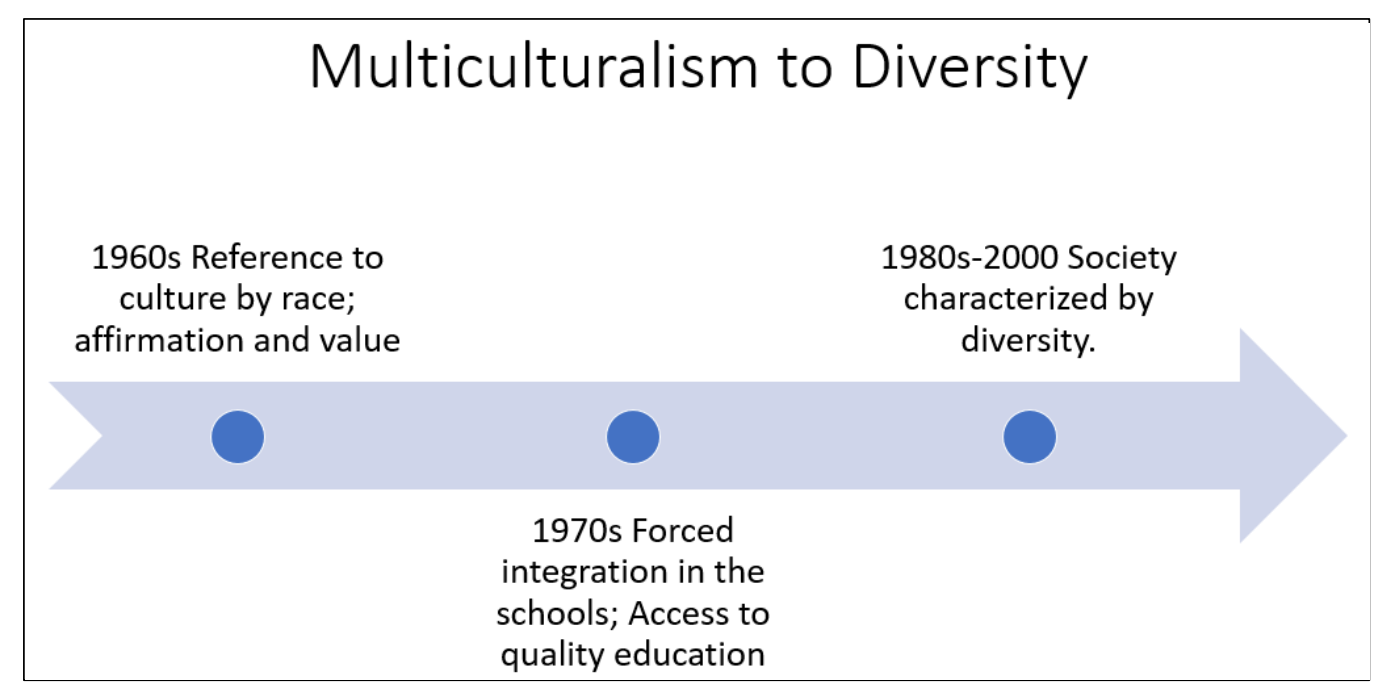

Figure 1. Timeline of Transition to Diversity Model

\section{Diversity}

As of 2018, articles are appearing in our discipline that speak of human rights as opposed to civil rights; cultural-linguistic diversity (Farrugia-Bernard, 2018; Quach \& Piz-Tzu, 2017) as opposed to multiculturalism with affirmation of racial-ethnic minorities (Baptiste \& Michal, 2004; Burgess, et al., 1989; Chow, 2014); and identification of bias in professional attitudes as opposed to direct and observable acts of discrimination (Franca, Smith, Nichols, \& Balan, 2016). The issues we currently study are harder to address than in past years. Bias is an internal response that takes longer to modify than a direct act of exclusion (i.e., segregation laws). It is difficult, yet important, to listen to opposing opinions and consider the life experiences that lead to the expression of differing opinions and the nurturance of broadly different perspectives on what to teach, how to teach, and decisions about admissions. It is also critical to explore the knowledge base that neuroscience provides regarding the impact of diversity for learning and scholarship (i.e., Lytton, 2002). A basic assumption of diversity gleaned from the literature review completed for this article is that the learning experience is enriched when learning occurs in the context of individuals who differ from one another. Thousands of articles and blogs address diversity and are readily available through ASHAwire (e.g., Bellon-Harn \& Weinbaum, 2017a; Bellon-Harn \& Weinbaum 2017b; Rodriquez, 2016). For example, Bellon-Harn and Weinbaum (2017a) discuss a pilot program at Lamar University in southeast Texas to increase the diversity of candidates in speech-language pathology and audiology to better reflect the diversity of the general population in Texas. Along with emphasizing community college partnerships with larger universities, the authors emphasize the importance of awareness and personal contact with students. An additional example is from Bellon-Harn and Weinbaum (2017b) who developed a cross-cultural peer-mentoring program to increase the numbers of racial-ethnic minority groups in graduate programs. This resonates 
strongly with me, since increasing awareness of my professional choices as an undergraduate through guidance from instructors and active professional exploration were factors that supported my success. Once recruited and enrolled as candidates, instruction and mechanisms for dealing with the unique needs of diverse learners, particularly racial-ethnic minorities, is critical. Evidence certainly suggests that sensitivity to difference and a recognition that difference does not automatically signal a lack of competence has potential for increasing inclusion and enriching the profession of speech-language pathology.

\section{Summary and Conclusions}

As stated at the outset of this essay, as we prepare future scholars it is essential to appreciate the broader context in which current actions and themes have emerged. A discussion of the civil rights movement as historical context for sharing my personal story and recounting my journey to becoming a speech-language pathologist was provided. The civil rights movement in the United States, particularly the period of 1950 s to 1960 s, led to the passage of laws to eliminate discrimination and to promote equitable treatment and access for voting, employment, housing and education. There were broad and sweeping influences across all sectors of society and disciplines, including speech-language pathology. It was a rich time of scholarship for many minority professionals who were addressing the bias in professional function that affected quality service to clients, as well as professional preparation of future clinicians. It was also a sobering time as many historically black schools were closed-even schools that were modern by the standard of the time as school boards implemented unreasonable integration; therefore, with bias (Martin, 1992). The discipline of speech-language pathology has been affected by the historical context over the years. It is important to consider how and what actions should be taken as a result.

The paradox is that while civil rights served to integrate the prevailing society and the institutions that maintain a society, forced integration dismantled some of the very support systems that insulated and nurtured minority children's development, particularly character and moral development. For example, in the community where I lived as a child, the Catholic schools devoted to educating black children all closed, beginning in the 1960s, and ending in the 1970s with the full implementation of integration. Catholic schools still exist in the region and my home state; however, without targeted recruitment efforts for Black children. Moreover, funding is more challenging as private schools must depend on tuition and other sources of funding. Without my early solid education, I doubt that I would have been competitive in high school, college or graduate school. I ponder the children lost because of the removal of a significant safety net of private schools and neighborhood communities of supports.

Both multiculturalism and diversity, as I see it, were reactions to resolve the unintended and negative consequences of forced integration. The movements were resets to influence a valuing of difference. However, along with the benefits are additional problems. How does this play out with the right for free association? Diversity is maintained when diverse communities thrive. It seems we need both free association and bonding with whom we have similar characteristics, as well as stretches to associate with those unlike ourselves. As a child, my home community nurtured me where we shared a common bond across many factors. Later, I often observed that black communities had to bear the burden of integration. There was generally no cooperation and equal movement of whites to black schools comparable to the number of black students moved to white 
schools. For one example regarding the problems with desegregation, see Martin (1972) who discusses how local school boards often closed Black schools, with these children bearing the burden of integration. See also Cecelski (1994) who described the boycotts of African Americans in Hyde County, North Carolina that resisted desegregation orders that would have closed Black schools that had existed since Reconstruction. These are only two examples. An internet search will easily identify thousands of related articles. This caused much tension and differential sacrifice in many instances. We are dealing with the aftermath of a patchwork quilt of successes and failures as a result of civil rights and the lack of preparedness for successful and voluntary integration. Added to this is the challenge of developing professionals across all fields to serve competently and to value all people. This valuing is not a surface level virtue that can simply be added as a competency and checked off at the end of a two-year or six-year college program. Rather it comes by mentoring, experience, and devotion to a passion. This passion can be ignited, to a degree, by studying history and the influences upon the discipline of speech-language pathology. TLCSD has potential for significant contribution in this vein.

I suggest that in preparing scholars in the field of speech-language pathology, a broader discussion of civil rights and historical context should be considered in order to reduce the impact of bias in relating the stories of all, and not just clients, but professionals as well. This knowledge is needed in order to develop policies and practices reflective of a valuing of people, communities and institutions. Litigation can only go so far to address social issues. At the heart of change that is effective and lasting is also individual integrity, passion for teaching well and respect for the worth of people. I have addressed the progression from multiculturalism to an embrace of diversity. Yet, in spite of the embrace for multiculturalism and diversity, do speech-language pathologists still bear the weight of the bias that "standard English" is white English rather than simply a dialect of English - an effective tool which should be available to all speakers? Do we operate from unreasonable biases that affect our research, teaching, scholarship and commitment to inclusion? Consider the works of scholars, such as Wiggins (2014), Taylor (1986), Wolfram (1999), Anderson (1991) and many others.

By sharing a part of my story, I have provided examples to illustrate mechanisms that supported my success. These included family values for education, teacher advocates who were strong empathizers and prepared scholars, as well as actions of larger professional organizations operating at a macro-level to affect systemic change (i.e., the courts, the ASHA, NBASLH) which would eventually bolster my advancement in the field. Although, the impact of those influences came later in my development and were often not directly and readily observable. Another factor mentioned, though not discussed in detail, was the visibility of a speech-language pathology program on my college campus and its active recruiting at the local level. I stumbled into speechlanguage pathology, which was a field that was not typically a common choice in my growing-up years.

The present essay is offered in hopes of encouraging thoughtful dialogue, as well as, consideration for broader aims and purposes for the journal. The need for a unifying pedagogy for teachingscholarship in the discipline of speech-language pathology is an important area of study. Future studies should consider the intended and unintended consequences of proposed actions to increase diversity within the profession. Without an understanding of the historical context, we are likely to miss valuable lessons that should guide the profession. 


\section{References}

Adler. S. (1988). A new job description and a new task for the public-school clinician: Relating effectively to the nonstandard dialect speaker. Language, Speech and Hearing Services in Schools, 19, 28-33.

American Speech-Language-Hearing Association. (1998). Students and professionals who speak english with accents and nonstandard dialects: issues and recommendations [Position Statement]. Retrieved from www.asha.org/policy.

American Speech-Language-Hearing Association. (2010). Cultural Competence Checklist: Personal reflection. Retrieved from www.asha.org/uploadedFiles/practice/multicultural/personalreflections.pdf.

Anderson, N. (1991). Understanding cultural diversity: Clinical consult. American Journal of Speech-Language Pathology, 1, 9-10.

Baptiste, H. P. \& Michal, E. J. (2004). Influences of three presidents of the United States on multicultural education: A series of research studies in education policy - Third installment: Examining Presidents John Quincy Adams, Theodore Roosevelt, and Harry S. Truman. Multicultural Education, 11(4), 35-45.

Battle, D. (2012). Communication Disorders in Multicultural Populations. St. Louis, MO: Mosby.

Bellon-Harn, M. \& Weinbaum, R. K. (2017a). Speech, language, and hearing careers: Recruiting students from diverse populations. Perspectives of the ASHA Special Interest Groups: Issues in Higher Education, 2(1), 4- 13. doi:10.1044/persp2.SIG10.4

Bellon-Harn, M. \& Weinbaum, R. (2017b). Cross-cultural peer-mentoring: Mentor outcomes and perspectives. Teaching and Learning in Communication Sciences \& Disorders, 1(2), Article 3. Retrieved from https://ir.library.illinoisstate.edu/tlcsd/vol1/iss $2 / 3$

Bias [Def.1a]. (n.d.). In Merriam-Webster Online, Retrieved from https://www.merriamwebster.com/dictionary/bias

Boersema, D. (2018). American Philosophy. In Internet Encyclopedia of Philosophy: A PeerReviewed Academic Resource. Retrieved from https://www.iep.utm.edu/american/

Bowen, S. K. (2016). Early Intervention: A Multicultural Perspective on Deaf and Hard of Hearing multilingual learners. American Annals of the Deaf, 161(1), 33-42.

Bowen, S. K. \& Correa-Torres, S. M. (2018). Understanding the communication needs of culturally and linguistically diverse students who are deafblind. Perspectives of the ASHA Special Interest Groups, 2 (12), 81-88. doi:10.1044/perwp2.SIG12.81

Bronfenbrenner, U, \& Morris, P. A. (2007). Handbook of child psychology. Wiley Online Library: John Wiley \& Sons. doi: 10.1002/9780470147658

Burgess, R., Burl, N. T., \& Calhoun, R. (1989). A Multicultural-Multidisciplinary Approach to Speech/Language Intervention with Black Children. Paper presented at the National Black Child Institute Conference. Retrieved from http://trace.tennessee.edu/utk_audipubs/7

Cecelski, D. S. (1994). Along Freedom Road: Hyde County, North Carolina, and the Fate of Black Schools in the South. Durham, NC: University of North Carolina Press.

Chow B. (2014). Multiculturalism. In Salem Press Encyclopedia [serial online]. Ipswich, MA: Research Starters.

Cobbs, E. \& Blum, E. (Eds.). (2015). Major problems in American history: Volume II: Since 1865 $\left(4^{\text {th }}\right.$ Ed.). Boston, MA.: Cengage Learning.

Cole, L. (1985). ASHA Interviews: Lorraine Cole, Office of Minority Concerns. ASHA, 27, 2325. 
Cox, W. E. (2004). Reflections of one who was there. In Anderson, J., \& Byrne, D. N. (Eds). The unfinished agenda of Brown V. Board of Education: Landmarks in civil rights history (p. xvii). Hoboken, N.J., John Wiley \& Sons.

Farrugia-Bernard, A. M. (2018). Speech-language pathologists as determiners of the human right to diversity in communication for school children in the US. International Journal of Speech-Language Pathology, 20(1), 170-173. doi:10.1080/17549507.2018.1406002

Flamm, M. C. (2018). George Santayana (1863-1952). Retrieved from http://www.iep.utm.edu/santayan/

Franca, M. C., Smith, L. M., Nichols, J. L., \& Balan, D. S. (2016). Culturally diverse attitudes and beliefs of students majoring in speech-language pathology. CoDAS, 28(5), 533-545. Retrieved from https://dx.doi.org/10.1590/2317-1782/20162015245

Lown, B. A. (2016). A social neuroscience-informed model for teaching and practicing compassion in health care. Medical Education, 50(3), 332-342.

Lytton, W. (2002). From computer to brain: Foundations of computational neuroscience. New York, NY: Springer-Verlag Publishing.

Martin, T. S. (1972). Inequality in Desegregation: Black School Closings. The University of Chicago Law Review, 39(3), 658-672. doi:10.2307/1598865

Rodriguez, J. C. (2016). Our clients are diverse: Why aren't we? ASHA Leader, 21, 40-42. doi:10.1044/leader.SSAY.21052016.40

Santayana, G. (1924). Reason in common sense. New York, NY: Charles Scribner's Sons.

Sisters of Christian Charity. (n.d.). Welcome to the Sisters of Christian Charity. Retrieved from https://scceast.org/

Taylor, O. L. (Ed.) (1986). Treatment of communication disorders in culturally and linguistically diverse populations. San Diego, CA: College-Hill Press.

Testa, D., \& Egan, R. (2014). Finding voice: the higher education experiences of students from diverse backgrounds. Teaching in Higher Education, 19(3), 229-241. doi: 10.1080/13562517.2013.860102

Quach, W., \& Pei-Tzu, T. (2017). Preparing Future SLPs for the Clinical World of CulturalLinguistic Diversity. Perspectives of The ASHA Special Interest Groups, 2(14), 82-102. doi:10.1044/persp2.SIG14.82

Wiggins, E. (2014). History of the National Black Association for Speech-Language and Hearing (NBASLH): The first twenty years: 1978-1998. Norfolk, VA: Poetica Publishing Co.

Wolfram, W. (1999). Dialects in schools and communities. Mawah, NJ: Lawrence Erlbaum Assoc. Inc. 